\title{
Research on The Influence of Enterprise Control Right Allocation on The Effectiveness of Internal Control -- Based on The Regulatory Role of Institutional Environment
}

\author{
Xia Bin ${ }^{1, *}$, Dong Kaili ${ }^{2, * *}$ \\ ${ }^{1}$ School of Economics and Management, Xi 'an University of Technology, Xi 'an, Shaanxi, China \\ ${ }^{2}$ School of Economics and Management, Xi 'an University of Technology, Xi 'an, Shaanxi, China
}

\begin{abstract}
In order to examine the influence degree of the enterprise control configuration of the internal control construction, this paper takes 2013-2018 a-share companies of Shanghai and Shenzhen two city as the research sample, using the methods of regression analysis method, from the three shareholders, the board of directors and managers control configuration level, to study the influence degree of the effectiveness of internal control, then to test system with regional marketization environment on the influence of the adjustment. The results show that the most effective allocation mode of internal control is as follows: at the shareholder level, the allocation mode is characterized by high equity balance and state-owned shares; at the level of the board of directors, it is manifested as the holding level of the high board of directors. At the level of managers, it shows the level of high managers' shareholding. This study has a good reference to improve the governance of listed companies.
\end{abstract}

\section{Introduction}

Since 2008, China has issued the "Basic Standards for Internal Control of Enterprises" and "Supporting Guidelines for Internal Control of Enterprises" to prevent the lack of internal control, and the effectiveness of internal control has therefore become a hot topic for scholars to study. First of all, the allocation of enterprise control power has a certain influence on the effectiveness of internal control. Because the shareholders, the board of directors and the general manager are not only the subjects of the allocation of control rights but also the subjects of internal control, there is a certain cross relationship between the two. Therefore, improving the allocation of corporate control power is more conducive to the internal control system. Secondly, the external environment of an enterprise may play a moderating role in the relationship between the allocation of control rights and the effectiveness of internal control. Therefore, we assume that the third party factor plays a moderating role in this influence mechanism. Currently, there are few researches in this field, and we finally choose "institutional environment" as the moderating factor. Through the above research, we hope to find out the control right allocation mode that can guarantee the effectiveness of internal control of enterprises.

\section{Theoretical analysis and research hypothesis}

\subsection{The allocation of control rights and the effectiveness of internal control at the shareholder level}

\subsubsection{Equity checks and balances and effectiveness of internal control}

"Equity checks and balances" refers to the checks and balances on the rights of shareholders other than the largest shareholder, and is generally expressed by the sum of the shareholding ratios of the second to the tenth largest shareholders. When the rights of the second to the tenth largest shareholders are enough to compete with the rights of the first largest shareholder, the supervision of the first largest shareholder can be strengthened, so as to effectively weaken the infringement of the rights of the other shareholders by the major shareholders. Through empirical analysis, Qin Xuejiao (2011) [1] and Gan Ting (2013) [2] found that the degree of equity checks and balances was positively correlated with the effectiveness of internal control. In view of the above analysis, we propose the following hypotheses:

H1: Equity checks and balances are positively correlated with the effectiveness of internal control. 


\subsubsection{Equity nature and effectiveness of internal control}

The state-owned enterprises are dominated by the state and reflect the will of the state, so they cannot give consideration to the interests of the enterprise and the regulating effect on the macro market, and the operation objective effect of internal control is poor. Zhang Weiying (2000) [3] believed that the arrangement of property rights in state-owned enterprises transformed economic organizations into political organizations, which would lead some managers to shift their focus from productive activities to power struggles. Therefore, we propose the following hypothesis:

H2: The ownership nature is negatively correlated with the effectiveness of internal control.

\subsection{Control control allocation and effectiveness of internal control at the board level}

Shareholding of the board of directors and effectiveness of internal control -- Members of the board of directors include shareholders. When the proportion of shareholders holding shares is large, it can be generally judged that shareholders hold a large number of seats, and the board of directors may be directly dominated by some shareholders. This may lead to some shareholders and directors jointly to do harm to the interests of other shareholders self-interested behavior. Therefore, we make the following assumptions:

H3: The shareholding ratio of the board of directors is negatively correlated with the effectiveness of internal control.

\subsection{The allocation of control rights and the effectiveness of internal control at the manager level}

General manager shareholding and effectiveness of internal control -- Equity incentive is a slightly effective way to solve the principal-agent problem. According to the research, the general manager holding the corresponding proportion of equity will strengthen his sense of belonging to the enterprise and his sense of identity to his own work, and effectively reduce the contradiction caused by the principal-agent problem. Through empirical analysis, Chen Tao (2018) [4] found that the equity incentive policy of senior executives was positively correlated with the effectiveness of internal control. Therefore, we propose the following hypothesis:

H4: The general manager's shareholding ratio is positively correlated with the effectiveness of internal control.

\subsection{The regulatory effect of the institutional environment}

Regional marketization degree -- The marketization index referred to in this paper refers to the development level and degree of regional marketization. The degree of marketization of each region is measured by the comprehensive index score in China Marketization Index -- Report on the Relative Process of Marketization of Various Regions compiled by Fan Gang et al. (2018). We speculate that the regions with higher marketization process can provide more beneficial development environment for enterprises and can regulate the behavior of enterprise management, thus strengthening the influence between the allocation of corporate control rights and the effectiveness of internal control. Therefore, the following assumptions are made:

H5: The degree of regional marketization has an enhanced moderating effect on the influence mechanism between control right allocation and the effectiveness of internal control.

\section{Research design}

\subsection{Sample selection and data sources}

In this paper, A-share companies in the Shanghai and Shenzhen stock markets from 2013 to 2018 were selected as the research samples, and the effectiveness indicators of internal control were comprehensively scored through the comprehensive evaluation model method. The relevant data of control control allocation were obtained from databases such as Guo-Tai 'an. In order to ensure the validity of the selected data, ST, *ST listed companies and abnormal data were excluded. Software Excel 2016 and SPSS 25.0 were used for data processing, statistics and analysis.

\subsection{Selection of variables}

Explained variable:

Based on the measurement criteria of the effectiveness of internal control in the research of Ding Weiguo (2018),[5] we adjusted them. By integrating COSO framework and internal control objectives, we scored the effectiveness of internal control in enterprises from four levels, and then weighted the comprehensive score based on a percentage system, as shown in Table 1.

Table 1. Internal control effectiveness measurement indicators

\begin{tabular}{|c|c|c|c|}
\hline $\begin{array}{c}\text { The target } \\
\text { level }\end{array}$ & Measure & Variable definitions & $\begin{array}{l}\text { Variable } \\
\text { representation }\end{array}$ \\
\hline \multirow[t]{2}{*}{$\begin{array}{l}\text { Business } \\
\text { Objectives }\end{array}$} & $\begin{array}{c}\text { Net } \\
\text { interest } \\
\text { rate on } \\
\text { total assets }\end{array}$ & $\begin{array}{c}\text { Net } \\
\text { Income/Average } \\
\text { Total Assets } * 100 \%\end{array}$ & \multirow{4}{*}{$\begin{array}{l}\text { Internal } \\
\text { control } \\
\text { integrated } \\
\text { score ICE }\end{array}$} \\
\hline & $\mathrm{P} / \mathrm{e}$ ratio & $\begin{array}{c}\text { Share price/EPS } \\
* 100 \%\end{array}$ & \\
\hline $\begin{array}{c}\text { Asset } \\
\text { Safety } \\
\text { Objectives }\end{array}$ & $\begin{array}{l}\text { Degree of } \\
\text { asset } \\
\text { protection }\end{array}$ & $\begin{array}{c}\text { Impairment loss on } \\
\text { assets/(impairment } \\
\text { loss on assets }+ \\
\text { total assets at the } \\
\text { end of the period) } \\
* 100 \%\end{array}$ & \\
\hline $\begin{array}{l}\text { Financial } \\
\text { Reporting } \\
\text { Objectives }\end{array}$ & $\begin{array}{l}\text { Opinion } \\
\text { on } \\
\text { financial } \\
\text { statements }\end{array}$ & $\begin{array}{l}\text { The dummy } \\
\text { variable, the } \\
\text { standard } \\
\text { unreserved opinion, }\end{array}$ & \\
\hline
\end{tabular}




\begin{tabular}{|c|c|c|c|}
\hline & audit & $\begin{array}{c}\text { takes value 1, } \\
\text { otherwise takes 0 }\end{array}$ & \\
\hline $\begin{array}{c}\text { Compliance } \\
\text { Goals }\end{array}$ & $\begin{array}{c}\text { This year } \\
\text { was } \\
\text { punished } \\
\text { by } \\
\text { regulators }\end{array}$ & $\begin{array}{c}\text { The dummy } \\
\text { variable, which is } \\
\text { punished by the } \\
\text { regulator, is 0, } \\
\text { otherwise it is 1 }\end{array}$ & \\
\hline
\end{tabular}

Explanatory variables

At the shareholder level, the allocation of control rights can be divided into two aspects: the degree of equity balance and the nature of equity. The board level is the shareholding ratio of the board of directors; the manager level is the general manager shareholding ratio.

Adjust the variable

The index of marketization process selects the data of 2017.

Control variables

Through studying the previous research works on the effectiveness of internal control, we decided to use the industry, whether the firm is top ten, company size, financial leverage as control variables, in order to ensure the accuracy of the experimental results.

To sum up, all the definitions and descriptions of variables set in this paper are shown in Table 2:

Table 2 Variable definition and description

\begin{tabular}{|c|c|c|c|}
\hline \multicolumn{2}{|c|}{ Variable name } & $\begin{array}{l}\text { Symbolic } \\
\text { representation }\end{array}$ & $\begin{array}{l}\text { Definition and } \\
\text { Description }\end{array}$ \\
\hline \multicolumn{4}{|c|}{ Explained variable: } \\
\hline & $\begin{array}{l}\text { Effectiveness } \\
\text { of internal } \\
\text { control }\end{array}$ & ICE & $\begin{array}{l}\text { Internal } \\
\text { control } \\
\text { effectiveness } \\
\text { score }\end{array}$ \\
\hline \multicolumn{4}{|c|}{ Explanatory variables: } \\
\hline \multirow{2}{*}{$\begin{array}{l}\text { Shareholder } \\
\text { level }\end{array}$} & Equity balance & IndexS & $\begin{array}{l}\text { The } \\
\text { shareholding } \\
\text { ratio of the } \\
\text { second to ten } \\
\text { largest } \\
\text { shareholders }\end{array}$ \\
\hline & $\begin{array}{l}\text { Nature of } \\
\text { equity }\end{array}$ & Nature & $\begin{array}{l}\text { Dummy } \\
\text { variable, } \\
\text { state-owned } \\
\text { enterprises } \\
\text { take } 1 \text {, } \\
\text { otherwise take } \\
0 \\
\end{array}$ \\
\hline $\begin{array}{l}\text { The board } \\
\text { of directors } \\
\text { level }\end{array}$ & $\begin{array}{l}\text { Shareholding } \\
\text { ratio of board }\end{array}$ & BoardHolding & $\begin{array}{l}\text { Sum of } \\
\text { shareholding } \\
\text { ratio of board } \\
\text { members }\end{array}$ \\
\hline $\begin{array}{l}\text { Managers' } \\
\text { level }\end{array}$ & $\begin{array}{l}\text { Shareholding } \\
\text { ratio of } \\
\text { general } \\
\text { manager }\end{array}$ & DirectHolding & $\begin{array}{l}\text { Shareholding } \\
\text { ratio of general } \\
\text { manager }\end{array}$ \\
\hline \multicolumn{4}{|c|}{ Adjusting variables: } \\
\hline & $\begin{array}{l}\text { Marketization } \\
\text { index }\end{array}$ & MarketIndex & $\begin{array}{l}\text { Marketization } \\
\text { index of } \\
\text { Chinese } \\
\text { provinces }\end{array}$ \\
\hline \multicolumn{4}{|c|}{ Control variables: } \\
\hline & $\begin{array}{l}\text { Whether the } \\
\text { firm is in the } \\
\text { top ten }\end{array}$ & AuditTop10 & $\begin{array}{l}\text { Dummy } \\
\text { variables, ten } \\
\text { to one, } \\
\text { otherwise zero }\end{array}$ \\
\hline & $\begin{array}{l}\text { The company } \\
\text { size }\end{array}$ & Scale & $\begin{array}{l}\text { The natural } \\
\text { logarithm of }\end{array}$ \\
\hline
\end{tabular}

\begin{tabular}{|l|l|l|l|}
\hline \multicolumn{2}{|l|}{ Variable name } & $\begin{array}{l}\text { Symbolic } \\
\text { representation }\end{array}$ & $\begin{array}{l}\text { Definition and } \\
\text { Description }\end{array}$ \\
\hline & & & $\begin{array}{l}\text { the total assets } \\
\text { at the end of } \\
\text { the period }\end{array}$ \\
\hline & & & $\begin{array}{l}\text { (Net profit }+ \\
\text { income tax } \\
\text { expense }+ \\
\text { financial } \\
\text { expense)/(Net } \\
\text { profit }+ \\
\text { income tax } \\
\text { expense) }\end{array}$ \\
\hline & Financial & DFL & \\
\hline
\end{tabular}

\subsection{Model construction}

In this paper, the following regression models are constructed from three levels of shareholders, board of directors and managers respectively to study the influence mechanism of control right allocation on the effectiveness of internal control and the regulatory effect of institutional environment.

\subsubsection{Shareholder-level model setting}

Model 1-0:

$$
\begin{aligned}
& I C E=\alpha+\beta_{1} \text { Index }+\beta_{2} N \text { ature }+\beta_{3} A \text { udit } T \text { op } 10 \\
& +\beta_{4} S \text { cale }+\beta_{5} D F L+\delta
\end{aligned}
$$

Model 1-1:

$I C E=\alpha+\beta_{1}$ Index $+\beta_{2} N$ ature $+\beta_{3}$ MarketIndex $+\beta_{4}$ Index

$\times$ MarketIndex $+\beta_{5} N$ ature $\times$ MarketIndex $+\beta_{6}$ AuditTopl 0

$+\beta_{7}$ Scale $+\beta_{8} D F L+\delta$

Among them, the variable containing " $\times$ " is the interaction item of explanatory variables and moderating variables at the shareholder level, which is set to test the regulatory effect of institutional environment. (the same below)

\subsubsection{Setting of board level model}

Model 2-0:

$$
\begin{aligned}
& I C E=\alpha+\beta_{1} \text { BoardHoldi ng }+\beta_{2} A \text { udit Top } 10+ \\
& \beta_{3} \text { Scale }+\beta_{4} D F L+\delta
\end{aligned}
$$

Model 2-1:

$I C E=\alpha+\beta_{1}$ BoardHolding $+\beta_{2}$ MarketIndex $+\beta_{3}$ Board

Holding $\times$ MarketIndex $+\beta_{4}$ AuditTop10 $+\beta_{5}$ Scale $+\beta_{6} D F L+\delta$

\subsubsection{Manager-level model setting}

Model 3-0:

$I C E=\alpha+\beta_{1}$ DirectHold ing $+\beta_{2} A$ udit Top $10+\beta_{3}$ Scale $+\beta_{4} D F L+\delta$

Model 3-1:

$I C E=\alpha+\beta_{1}$ DirectHoldng $+\beta_{2}$ MarketInde $+\beta_{3}$ DirectHoldng $\times$ MarketIndex $+\beta_{4} A$ uditTop10 $+\beta_{5}$ Scale $+\beta_{6} D F L+\delta$ 


\section{Empirical analysis}

\subsection{Descriptive statistics}

Descriptive statistics were made for 2845 groups of effective data after screening and sorting. The results are shown in Table 3:

Table 3. Descriptive Statistics

\begin{tabular}{|c|c|c|c|c|c|c|c|c|}
\hline & $\begin{array}{c}\text { Number } \\
\text { of } \\
\text { samples }\end{array}$ & $\begin{array}{c}\text { The } \\
\text { average }\end{array}$ & $\begin{array}{l}\text { The } \\
\text { median }\end{array}$ & $\begin{array}{c}\text { The } \\
\text { minimum } \\
\text { value }\end{array}$ & $\begin{array}{c}\text { The } \\
\text { proportion }\end{array}$ & $\begin{array}{c}\text { The } \\
\text { maximum }\end{array}$ & $\begin{array}{c}\text { The } \\
\text { proportion }\end{array}$ & $\begin{array}{c}\text { The } \\
\text { standard } \\
\text { deviation }\end{array}$ \\
\hline $\begin{array}{l}\text { Effectiveness of } \\
\text { internal control }\end{array}$ & 2845 & 71.84 & 73.59 & 10.67 & & 93.85 & & 11.59 \\
\hline Equity balance & 2845 & 26.78 & 26.24 & 1.55 & & 66.28 & & 11.99 \\
\hline Nature of equity & 2845 & & & 0.00 & $74.13 \%$ & 1.00 & $25.87 \%$ & \\
\hline $\begin{array}{c}\text { Shareholding ratio of } \\
\text { board }\end{array}$ & 2845 & 17.26 & 6.33 & 0.00 & & 89.18 & & 20.47 \\
\hline $\begin{array}{l}\text { Shareholding ratio of } \\
\text { general manager }\end{array}$ & 2845 & 1.39 & 0.00 & 0.00 & & 99.10 & & 6.55 \\
\hline Marketization index & 2845 & 8.58 & 9.26 & 0.52 & & 10.60 & & 1.60 \\
\hline
\end{tabular}

The mean and median of the effectiveness of internal control are at the same level, indicating that the effectiveness level of internal control in the sample population is good. The range of minimum and maximum values is large, indicating that the effectiveness level of internal control in sample enterprises is low.

Among the two explanatory variables at the shareholder level, the mean and median of equity checks and balances are similar, indicating that the overall ownership structure is relatively concentrated. Enterprises with state-owned equity nature accounted for $25.87 \%$, indicating that state-owned enterprises accounted for a relatively small proportion in the sample enterprises.

The average shareholding of the board of directors is 17.26 , and the median of 6.33 is less than the mean, indicating that the shareholding level of the board of directors of half the number of enterprises is less than $6.33 \%$, and the standard deviation is 20.47 , indicating a large data dispersion level.

The mean value of the general manager's shareholding ratio is 1.39 , and the median value is 0 . The data vary from 0 to 99.1 , indicating that the shareholding ratio of general managers of different enterprises varies greatly, but the general managers of most enterprises do not hold shares.

In terms of institutional environment, the marketization index ranges from 0.52 to 10.6 , with an average of 8.58 , indicating that the marketization index of the office area where the sample enterprises are located is generally above the average level.

\subsection{Correlation analysis}

Before the regression of variables, this paper first tested the correlation degree among variables through Pearson correlation test, and the results are shown as follows:

Table 4. Correlation Analysis at the Shareholder Level

\begin{tabular}{|c|c|c|c|c|c|c|}
\hline & ICE & IndexS & Nature & AuditTop10 & Scale & DFL \\
\hline ICE & 1 & $.052 * *$ & .036 & -.030 & $-.086 * *$ & $-.046^{*}$ \\
\hline IndexS & & 1 & $-.210 * *$ & .015 & -.032 & -.035 \\
\hline Nature & & & 1 & .018 & $.364 * *$ & .005 \\
\hline AuditTop10 & & & & 1 & $.088^{* *}$ & -.019 \\
\hline $\begin{array}{l}\text { Scale } \\
\text { DFL }\end{array}$ & & & & & 1 & $\begin{array}{c}.022 \\
1\end{array}$ \\
\hline
\end{tabular}

Among the two explanatory variables at the shareholder level, the degree of equity checks and balances is positively correlated with the effectiveness of internal control at the significance level of $1 \%$, while the nature of equity has no significant correlation with the effectiveness of internal control. 
Table 5. Correlation analysis of board shareholding ratio

\begin{tabular}{|c|c|c|c|c|c|}
\hline & ICE & BoardHolding & AuditTop10 & Scale & DFL \\
\hline ICE & 1 & $.060^{* *}$ & -.030 & $-.086^{* *}$ & $-.046^{*}$ \\
\hline BoardHolding & & 1 & .005 & $-.408^{* *}$ & $-.072^{* *}$ \\
\hline AuditTop10 & & & 1 & $.088^{* *}$ & -.019 \\
\hline Scale & & & & 1 & $.077^{* *}$ \\
\hline DFL & & & & & 1 \\
\hline
\end{tabular}

The board shareholding ratio is positively correlated with the effectiveness of internal control at the significance level of $1 \%$.

Table 6. Correlation analysis of general manager shareholding ratio

\begin{tabular}{cccccc}
\hline & ICE & $\begin{array}{c}\text { Direct } \\
\text { Holding }\end{array}$ & $\begin{array}{c}\text { Audit } \\
\text { Top10 }\end{array}$ & Scale & DFL \\
\hline ICE & 1 & $.042^{*}$ & -.030 & $-.086^{* *}$ & $-.046^{*}$ \\
DirectHolding & 1 & -.012 & $-.070^{* *}$ & -.004 \\
AuditTop10 & & 1 & $.088^{* *}$ & -.019 \\
Scale & & & 1 & $.077^{* *}$ \\
DFL & & & & 1 \\
\hline
\end{tabular}

**. There was a significant correlation at the.01 level (bilateral). *. Significant correlation at 0.05 level (bilateral).

The general manager shareholding ratio is positively correlated with the effectiveness of internal control at the significance level of $5 \%$.

In the three tables, the correlation coefficients among explanatory variables, control variables and regulating

variables are all less than 0.5 , indicating that there is no serious collinearity problem between explanatory variables, control variables and regulating variables.

\subsection{Regression test and result analysis}

Table 7. Results of multiple linear regression at the shareholder level

\begin{tabular}{|c|c|c|c|c|}
\hline \multirow[t]{2}{*}{ The variable name } & \multicolumn{4}{|c|}{ The coefficient and the value of $\mathrm{T}$} \\
\hline & Model 1 to 0 & & Model 1 to 1 & \\
\hline Equity balance & $\begin{array}{r}0.063 \\
(3.421)\end{array}$ & $* * *$ & $\begin{array}{c}0.056 \\
(3.032)\end{array}$ & $* * *$ \\
\hline Nature of equity & $\begin{array}{r}2.236 \\
(4.112) \\
\end{array}$ & $* * *$ & $\begin{array}{r}2.023 \\
(3.627)\end{array}$ & $* * *$ \\
\hline Marketization index & & & $\begin{array}{c}-0.069 \\
(-0.483)\end{array}$ & \\
\hline $\begin{array}{l}\text { Equity checks and balances * } \\
\text { marketization index }\end{array}$ & & & $\begin{array}{l}0.013 \\
(1.145)\end{array}$ & \\
\hline Equity nature $*$ marketization index & & & $\begin{array}{c}0.669 \\
(2.151)\end{array}$ & $* *$ \\
\hline Whether the firm is in the top ten & $\begin{array}{l}-0.558 \\
(-1.273)\end{array}$ & & $\begin{array}{l}-0.462 \\
(-1.042)\end{array}$ & \\
\hline The company size & $\begin{array}{l}-0.808 \\
(-4.297)\end{array}$ & $* * *$ & $\begin{array}{c}-0.759 \\
(-4.025)\end{array}$ & $* * *$ \\
\hline Financial leverage & $\begin{array}{l}-0.288 \\
(-1.962)\end{array}$ & $* *$ & $\begin{array}{c}-0.294 \\
(-1.982) \\
\end{array}$ & $* *$ \\
\hline $\mathrm{R}^{2}$ variation & 0.025 & & 0.027 & \\
\hline F variation & 7.272 & & 5.228 & \\
\hline
\end{tabular}

Table 8. Results of multiple linear regression at the board level

\begin{tabular}{|c|c|c|}
\hline \multirow[t]{2}{*}{ The variable name } & \multicolumn{2}{|c|}{ The coefficient and the value of $\mathrm{T}$} \\
\hline & Model 2 to 0 & Model 2 to 1 \\
\hline
\end{tabular}




\begin{tabular}{|c|c|c|c|c|}
\hline \multirow[t]{2}{*}{ The variable name } & \multicolumn{4}{|c|}{ The coefficient and the value of $\mathrm{T}$} \\
\hline & Model 2 to 0 & & 2 to 1 & \\
\hline Shareholding ratio of board & $\begin{array}{r}0.019 \\
(1.657) \\
\end{array}$ & $*$ & $\begin{array}{r}0.021 \\
(1.806) \\
\end{array}$ & $*$ \\
\hline Marketization index & & & $\begin{array}{r}-0.121 \\
(-0.866) \\
\end{array}$ & \\
\hline $\begin{array}{l}\text { Board shareholding ratio * } \\
\text { Marketization index }\end{array}$ & & & $\begin{array}{r}-0.008 \\
(-1.273) \\
\end{array}$ & \\
\hline Whether the firm is in the top ten & $\begin{array}{l}-0.668 \\
(-1.521)\end{array}$ & & $\begin{array}{l}-0.617 \\
(-1.390)\end{array}$ & \\
\hline The company size & $\begin{array}{l}-0.452 \\
(-2.387)\end{array}$ & $* *$ & $\begin{array}{l}-0.416 \\
(-2.184)\end{array}$ & $* * *$ \\
\hline Financial leverage & $\begin{aligned} &-0.324 \\
&(-2.201) \\
&\end{aligned}$ & $* *$ & $\begin{array}{r}-0.328 \\
(-2.207) \\
\end{array}$ & $* *$ \\
\hline $\mathrm{R}^{2}$ variation & 0.017 & & 0.019 & \\
\hline$F$ variation & 6.054 & & 4.817 & \\
\hline
\end{tabular}

Table 9. Results of multiple linear regression at the manager level

\begin{tabular}{|c|c|c|c|c|}
\hline \multirow[t]{2}{*}{ The variable name } & \multicolumn{4}{|c|}{ The coefficient and the value of $\mathrm{T}$} \\
\hline & Model 3 to 0 & & Model 3 & to 1 \\
\hline $\begin{array}{l}\text { Shareholding ratio of general } \\
\text { manager }\end{array}$ & $\begin{array}{r}0.062 \\
(1.879)\end{array}$ & * & $\begin{array}{l}0.073 \\
(2.087)\end{array}$ & $*$ \\
\hline Marketization index & & & $\begin{array}{r}-0.175 \\
(-1.120) \\
\end{array}$ & \\
\hline $\begin{array}{l}\text { General Manager and Chairman* } \\
\text { Marketization index }\end{array}$ & & & $\begin{array}{r}-0.031 \\
(-1.116) \\
\end{array}$ & \\
\hline Whether the firm is in the top ten & $\begin{array}{l}-0.584 \\
(-1.331)\end{array}$ & & $\begin{array}{l}-0.489 \\
(-1.101)\end{array}$ & \\
\hline The company size & $\begin{array}{l}-0.564 \\
(-3.103)\end{array}$ & $* *$ & $\begin{array}{l}-0.535 \\
(-2.931)\end{array}$ & $* * *$ \\
\hline Financial leverage & $\begin{array}{l}-0.333 \\
(-2.266) \\
\end{array}$ & $* *$ & $\begin{array}{r}-0.330 \\
(-2.220) \\
\end{array}$ & $* *$ \\
\hline $\mathrm{R}^{2}$ variation & 0.016 & & 0.021 & \\
\hline $\mathrm{F}^{2}$ variation & 5.143 & & 4.527 & \\
\hline
\end{tabular}

Note: $* * *, * *$ and $*$ refer to significant correlations at levels $0.01,0.05$ and 0.1 , respectively

At the shareholder level, the degree of equity checks and balances is significantly positively correlated with the effectiveness of internal control at the $1 \%$ confidence level, and hypothesis $\mathrm{H} 1$ is accepted. The equity nature is positively correlated with the effectiveness of internal control at the significance level of $1 \%$, indicating that the internal control system of state-owned enterprises operates effectively. Therefore, hypothesis $\mathrm{H} 2$ is passed in the opposite direction.

In the test of the regulatory effect of institutional environment, marketization index has an enhanced regulatory effect on the effectiveness of internal control of state-owned enterprises, indicating that the higher the level of market development, the more obvious the enhanced effect of these factors. So let's say that $\mathrm{H} 5$ is partially verified.

The shareholding ratio of the board of directors is positively correlated with the effectiveness of internal control at the significance level of $10 \%$, so it is assumed that $\mathrm{H} 3$ passes in the opposite direction.

In the test of the moderating effect of institutional environment, the moderating effect of market index on the relationship between board shareholding ratio and the effectiveness of internal control is not significant. Therefore, suppose that $\mathrm{H} 5$ is partially verified.

At the manager level, the shareholding ratio of the general manager is positively correlated with the effectiveness of internal control at the significance level of $10 \%$. Hypothesis $\mathrm{H} 4$ is accepted.

In the regulatory effect test of institutional environment, the market index has no significant effect on the positive correlation between GM shareholding ratio and the effectiveness of internal control. So suppose that H5 is partially verified.

\subsection{Robustness test}

In order to test the robustness of the hypothetical results described in this paper, the following arrangements are used for testing: (1) The calculation method of equity balance degree is changed to: the ratio between the sum of the top five shareholders' shareholding ratio and the largest shareholder's shareholding ratio; (2) "Executive shareholding ratio" replaces the original variable, General Manager shareholding ratio. The results of multiple linear regression 
in the robustness test part can maintain a high degree of consistency with the above, and there is no substantial change that is significantly different from the above. Therefore, the empirical test results of this paper are robust.

Table 10. Summary of hypothesis test results

\begin{tabular}{|c|c|c|c|}
\hline $\begin{array}{c}\text { Serial } \\
\text { number }\end{array}$ & $\begin{array}{l}\text { Inspection } \\
\text { level }\end{array}$ & $\begin{array}{l}\text { Assuming that } \\
\text { the content }\end{array}$ & $\begin{array}{c}\text { The } \\
\text { verification } \\
\text { results }\end{array}$ \\
\hline H1 & \multirow{2}{*}{$\begin{array}{c}\text { Shareholder } \\
\text { level }\end{array}$} & $\begin{array}{l}\text { The degree of } \\
\text { equity balance } \\
\text { is positively } \\
\text { correlated } \\
\text { with the } \\
\text { effectiveness } \\
\text { of internal } \\
\text { control }\end{array}$ & through \\
\hline $\mathrm{H} 2$ & & $\begin{array}{l}\text { The } \\
\text { ownership } \\
\text { nature is } \\
\text { negatively } \\
\text { correlated } \\
\text { with the } \\
\text { effectiveness } \\
\text { of internal } \\
\text { control }\end{array}$ & $\begin{array}{l}\text { Reverse } \\
\text { through }\end{array}$ \\
\hline $\mathrm{H} 3$ & $\begin{array}{l}\text { The board } \\
\text { of directors } \\
\text { level }\end{array}$ & $\begin{array}{l}\text { The } \\
\text { proportion of } \\
\text { independent } \\
\text { directors is } \\
\text { negatively } \\
\text { correlated } \\
\text { with the } \\
\text { effectiveness } \\
\text { of internal } \\
\text { control }\end{array}$ & $\begin{array}{l}\text { Reverse } \\
\text { through }\end{array}$ \\
\hline H4 & $\begin{array}{l}\text { Managers' } \\
\text { level }\end{array}$ & $\begin{array}{l}\text { The general } \\
\text { manager } \\
\text { shareholding } \\
\text { ratio is } \\
\text { positively } \\
\text { correlated } \\
\text { with the } \\
\text { effectiveness } \\
\text { of internal } \\
\text { control }\end{array}$ & through \\
\hline H5 & $\begin{array}{l}\text { Adjust the } \\
\text { role }\end{array}$ & $\begin{array}{l}\text { The degree of } \\
\text { regional } \\
\text { marketization } \\
\text { has an } \\
\text { enhanced } \\
\text { moderating } \\
\text { effect on the } \\
\text { influence } \\
\text { mechanism } \\
\text { between the } \\
\text { allocation of } \\
\text { control rights } \\
\text { and the } \\
\text { effectiveness } \\
\text { of internal } \\
\text { control }\end{array}$ & Partly by \\
\hline
\end{tabular}

\section{Research conclusions and recommendations}

\subsection{Research Conclusions}

The degree of equity balance can have a significant positive impact on the effectiveness of internal control. It shows that when the minority shareholder can compete with the largest shareholder, the effectiveness of enterprise internal control is significantly enhanced; there is a positive correlation between the ownership nature and the effectiveness of internal control. The internal control of state-owned enterprises is more effective than that of non-state-owned enterprises. The shareholding ratio of the board of directors has a significant positive effect on the effectiveness of internal control. The general manager shareholding ratio can have a significant positive impact on the effectiveness of internal control; the degree of regional marketization has a significant effect on the relationship between the degree of equity balance, the nature of equity, the general manager's shareholding ratio and the effectiveness of internal control.

To sum up, we believe that the following control control allocation modes are most conducive to the effective design and implementation of the internal control system of enterprises:

Table 11. The control right configuration mode with the highest effectiveness of enterprise internal control

\begin{tabular}{cc}
\hline $\begin{array}{c}\text { Control control } \\
\text { allocation level }\end{array}$ & Indicators \\
\hline Shareholder & High equity balance degree; \\
level & Contains state - owned component \\
Board level & High board shareholding level \\
Manager level & The shareholding level of high \\
managers
\end{tabular}

At the same time, we can draw a conclusion from the research results: the higher the marketization level, the more significant the influence of enterprise control right allocation on the effectiveness of internal control.

\subsection{Advice}

(1) Enterprises should optimize the ownership structure. Maintain a high degree of equity balance. (2) Enterprises need to improve the board of directors governance mechanism. The board of directors keeping a high level of shareholding can strengthen the supervision of the board of directors and shareholders on the managers, so as to enhance the effectiveness of internal control of enterprises. (3) Enterprises should strengthen the independence of managers. Avoid the general manager and chairman of the board of directors concurrent behavior. (4) Enterprises should also make reasonable use of the equity incentive mechanism. The higher shareholding level of the board of directors and the general manager can improve the effectiveness of internal control. Therefore, enterprises should use equity incentive tools to strengthen executives' sense of belonging and identity to the enterprise. (5) A higher level of market-oriented development can promote the influence of control right allocation on the effectiveness of internal 
control of enterprises. Therefore, the government should take measures according to local conditions and formulate diversified economic development policies to balance the economic development level of each region.

\section{Reference}

1. Qin Xuejiao. Influence of Corporate Governance Structure on the Effectiveness of Internal Control [D]. Dongbei University of Finance and Economics,2011.

2. Gan Ting. Research on the Influence of Control Rights Allocation on Internal Control Effectiveness of Listed Companies in China [D]. Southwestern University of Finance and Economics, 2013.

3. Zhang W Y. The arrangement of property rights and the power struggle within enterprises [J]. Economic Research Journal,2000(06):41-50+78.

4. Chen Tao. Research on the Choice and Allocation of Control Mode of Entrepreneurial Enterprises [D]. Xi 'an University of Technology, 2018.

5. Ding Weiguo. The Impact of Independent Director Governance on Corporate Financial Risks -- A Study on the Moderating Effect Based on Institutional Environment [J]. Economic Issues, 2018(09):101-107+119. 